\title{
An Overview of Insurance Services in Nepal
}

\author{
Prof. Dr. Puspa Raj Sharma
}

The present scenario of micro (finance and insurance) seems a lot of uncertainty. Naturally uncertainty gives birth to risk. Therefore, the need for risk-management solutions is undisputed by policy makers, who are aware that poor families can lose - in a matter of hours - assets that took years to accumulate, due to a sudden sickness or accident. The policy to provide free primary care and to a certain degree secondary care is positive step and could effectively help to reduce financial exposure of Nepal's poor when the policy is implemented and functional on large scale. But even if this would succeed, only a part of the vulnerability is reduced: the poor still have to pay for services not covered under this policy, such as certain hospitalization cases, the transportation to health care providers, wageloss - to name a few. The poor households currently need to finance huge amounts of health expenses (out of pocket expenditure) which are over and above their current income(s) and savings. They therefore need to resort to multiple sources of financing, of which a major source is borrowing. At present, there are 25 registered insurance companies in Nepal. Of these, 8 are private commercial life insurers, 16 are private commercial non-life insurers and 1 is composite insurer, i.e., Rastriya Beema Sansthan owned by the government.

Key words: Micro insurance, Risk Management, poverty, microfinance

\section{Introduction - Micro insurance}

In the movement of Microfinance -micro insurance also plays vital role for its success. There is a simple and proven tool to reduce the vulnerability to the financial consequences of ill health: insurance. Unlike the burden of financing huge health expenses from current income or through borrowing, insurance uses a solidarity mechanism and spreads the costs of illness over many households. It thus reduces the burden on the effected household. Furthermore, insurance converts unpredictable health expenses into predictable costs in form of health insurance premiums. This makes financial planning for households much easier and reduces the need to borrow money in an emergency situation at unfavorable rates. Health insurance can do more than only covering the medical costs: it can also provide coverage for the indirect costs, such as loss of income during hospitalization or the cost of transportation to the hospital. Health insurance can thus play an important role to reduce the vulnerability of the poor( Sharma, 2011). 
Janapriya Journal of Interdisciplinary Studies, Vol. 2, No.1 (December 2013)

Micro Insurance is a new concept and still in a nascent stage in developing countries including Nepal. Generally, it is a means of protecting the low income households from risks and alleviating poverty. However, the concept of micro insurance means different things to different people. Insurance regulators see its nature as the insurance scheme designed for low income sector based on insurance principles and funded by premiums. Commercial insurers consider its potential as a way of reaching large underserved markets. Development institutions, such as, the United Nations, the World Bank and Asian Development Bank, highlight its potential to secure poverty alleviation. Financial journalists and analyst focus the size of markets at the "bottom of the pyramid". General publics argue that the transfer of risks by low-income households to insurers.

There is no universally accepted definition of micro insurance. Academics and institutions have defined micro insurance in different ways. (Box 1)

\section{Box 1 : Definition of Micro Insurance}

International Association of Insurance Supervisors (IAIS)

"Micro Insurance is insurance that is accessed by low-income population, provided by a variety of different entities, but run in accordance with generally accepted insurance practices. Importantly, this means that the risk insured under a micro insurance policy is managed based on insurance principles and funded by premiums"

\section{The World Bank}

"Micro Insurance is an insurance product to improve a low-income person's quality of life by allowing the person to better manage potential problems while empowering that person to be more proactive as to the future".

\section{Asian Development Bank}

"Micro Insurance refers to the insurance products that are designed to be beneficial and affordable to low-income individuals or groups."

\section{ILO, Micro Insurance Innovation Facility (ILO-MIF)}

"Micro insurance is a mechanism to protect poor people against risk (accident, illness, death in the family, natural disasters, etc.) in exchange for insurance premium payments tailored to their needs, income and level of risk."

\section{Munich Re-Foundation}

"Micro insurance is the provision of insurance to low-income households that otherwise would not have access to insurance."

Micro insurance is aimed towards low-income households that may not be covered 
by other insurance and social security schemes. Important features of micro insurance products include ( Sharma, 2011):

- Designed to be appropriate to low-income household

- Comparatively low premium

- Coverage is simple and straight forward

- Distribution channels are different

- Simple methods of claim settlement

- Simple documentation process

Micro insurance draws on the same generally accepted practices as conventional insurance, viz., actuarial pricing, reinsurance and claim handling, there are fundamental differences between micro insurance and conventional insurance. (Box 2)

\section{Box 2: Micro Insurance vs. Conventional Insurance}

Micro insurance

Conventional Insurance

- Simple policy document with few, if - Complex policy document with any, exclusions. standard exclusions.

- Primarily group policies only

- Small sums insured

- Selling to individuals.

- Premium accommodate irregular cash flows, paid in cash or otherwise

- Primarily groups pricing and selling

- Period of coverage can be as short as 4 months.

- Screening requirements world be limited to a declaration of good health.

- Distribution channels manage the entire customer relationship, premium collection, etc.

- Market is largely unfamiliar with insurance.

- Claims process should be simple.

- Small and large sums insured

- Regular premium payments as banking transaction.

- Priced based on age/specific risk

- Usually minimum of 12 months.

- Screening requirements may include a medical examination.

- Agents and brokers are primarily responsible for sales.

- Market is largely familiar with insurance.

Claims process may be quite difficult for policyholders

Micro insurance is not only beneficial to low-income households; it is equally useful to insurance companies and intermediaries too ( Sharma, 2011). Micro insurance can generate profits by expanding activities of insurers in large rural markets. Micro insurance helps to get the company's brand name into the market. It helps to develop a good relationship with the regulator and government in new markets. Micro insurance can be presented as an act of corporate social responsibility.

The benefits of micro insurance for low-income households (policy holders), 
intermediaries, insurers and society at large are presented in Box 3.

\section{Box 3: Benefits of Micro insurance.}

A. Benefits for low-income households (Policyholders):

- Products adapted to client needs

- Products adapted to client capacity to pay

- Reduced focused on loss of life and livelihood.

- Insurance can improve ability to cope with loss.

B. Benefits for Intermediaries (Agents and Brokers)

- New line of business

- Large policyholders base

- Improve morale among employees

- Corporate social responsibility

- Enhance corporate image

- Increase commission earnings

- Training and capacity building

C. Benefits for Insurers (Insurance Companies)

- New line of business

- Large policyholder base

- Improve morale among employees

- Corporate social responsibility

- Enhance corporate image

- Increase profitability

D. Social Benefits

- Improved morale among rural communities

- Employment generation and women empowerment

- Increased ability to face problems

- Poverty alleviation tool

Box 4: Key Challenges of Micro Insurance :

From Policyholders (Clients) Perspective:

- Negative attitude towards insurance industry

- Lack of insurance knowledge as a risk management strategy

- Low and irregular income

- Information lacking

- High default/lapsetion rates (lack of cash)

- Lack of client friendly products.

From Delivery Channels Perspective:

- Lack of institutional infrastructure (delivery channels and training institutions)

- Lack of insurance competence

- Slow claims handling /complicated documentation process

- Conflict 


\section{From Insurers Perspective}

- $\quad$ Lack of knowledge of the micro insurance market

- Very risky business (Catastrophe, high mortality rate)

- High transaction cost per client (remote areas, record-keeping, collection costs, communication costs, etc.)

- Large volume but low margins due to low premium

- Unknown potential market (No statistics, experience)

- Low risk retention capacity

- Very strict claims provision (may be 30 days)

\section{From Regulators Perspective}

- Lack of Awareness

- Micro insurance regulation

- Capacity building (Training for ......... )

- Issue of subsidies in micro insurance.

- Access to reinsurance capacity

\section{Status of Insurance in Nepal}

The history of insurance industry in Nepal is not long. It has its roots in the $20^{\text {th }}$ century. The first insurance company, "Nepal Insurance and Transport Company Ltd" (now named Nepal Insurance Co. Ltd) was established in 1947 (2004 BS) . Prior to that most of the branches of the Indian insurers were doing business in Nepal which was not regulated.

The number of insurance companies by mid-March 2012 totalled 25 including 8 companies dealing with life insurance, 16 with non-life insurance and one with both life and nonlife insurance. From ownership structure perspective, 3 insurance companies are operating with full foreign capital investment, while 3 of them are operating as joint capital venture of foreign Insurance companies. Similarly, 18 companies are under private ownership and the government of Nepal owns one Insurance company. The total resource/ utilization of these insurance companies increased by 9.8 percent to Rs. 67.18 billion by mid-March 2012 from 61.28 billion in mid-July 2011. By mid-July, 2011, insurance companies have collected a total premium of Rs. 17.48 billion from both the life and non-life insurances while this premium figure was Rs. 15.26 billion in the same period of last year (Economic Survey, 2012/13) . 
Table:1 Ownership Pattern of Insurance Companies.

\begin{tabular}{|l|l|l|l|l|}
\hline \multirow{2}{*}{ Ownership } & \multicolumn{2}{|l|}{ Nature of Company } & Total \\
\cline { 2 - 4 } & Life & Non-life & Composite & \\
\hline Government & - & - & 1 & 1 \\
Private & 5 & 13 & - & 18 \\
Foreign & 1 & 2 & - & 3 \\
Joint Venture & 2 & 1 & - & 3 \\
\hline Total & 8 & 16 & 1 & 25 \\
\hline
\end{tabular}

Source : Economic survey, 2012/13

The total financial source and their utilization of life and non-life insurance companies operating in the country by mid-July of 2011 have reached Rs 61,213.4 million, which is 22.46 percent growth as compared to the previous fiscal year. By mid-January of 2012, such amount has reached to Rs. 67,183.4 million (Economic Survey, 2012/13).

Table : 2 Sources and Utilization of Life and Non-Life Insurance Companies* (In million Rs.)

\begin{tabular}{|l|l|l|l|l|l|l|l|l|}
\hline & \multicolumn{2}{|c|}{ FY 2008/09 } & \multicolumn{2}{c|}{ FY 2009/10 } & \multicolumn{2}{c|}{ FY 2010/11 } & \multicolumn{2}{c|}{ FY 2011/12** } \\
\hline Resource & Life & Nonlife & Life & Nonlife & Life & Nonlife & Life & Nonlife \\
\hline a) Paid up capital & $1,647.3$ & $1,270.4$ & 1,890 & $1,560.0$ & $2,451.4$ & $1,642.0$ & $2,451.4$ & $1,642.0$ \\
\hline b) Reserve Fund & $26,425.4$ & $2,383.7$ & 33,250 & $4,060.0$ & $44,040.0$ & $6,830.0$ & $48,020.0$ & $7,850.0$ \\
\hline c) Other Liabilities & $1,565.0$ & $3,722.5$ & 2,980 & $3,720.0$ & $2,750.0$ & $3,500.0$ & $3,200.0$ & $4,020.0$ \\
\hline Utilization & $\mathbf{2 9 , 6 3 7 . 7}$ & $\mathbf{7 , 3 7 6 . 6}$ & $\mathbf{3 8 , 1 2 0}$ & $\mathbf{9 , 3 4 0 . 0}$ & $\mathbf{4 9 , 2 4 1 . 4}$ & $\mathbf{1 1 , 9 7 2 . 0}$ & $\mathbf{5 3 , 6 7 1 . 4}$ & $\mathbf{1 3 , 5 1 2 . 0}$ \\
\hline $\begin{array}{l}\text { a) Cash in Bank } \\
\text { and at Hand }\end{array}$ & $1,079.9$ & 657.5 & 920 & 700.0 & 750.0 & 900.0 & 820.0 & 980.0 \\
\hline b) Investment & $26,062.9$ & $4,966.9$ & 33,500 & $6,700.0$ & $44,491.4$ & $8,202.0$ & $48,491.4$ & $8,942.0$ \\
\hline c) Fixed Asset & 566.2 & 522.3 & 1,540 & 870.0 & $2,100.0$ & $1,070.0$ & $2,290.0$ & $1,270.0$ \\
\hline d) Other Assets & $1,928.7$ & $1,229.9$ & 2,160 & $1,070.0$ & $1,900.0$ & $1,800.0$ & $2,070.0$ & $2,320.0$ \\
\hline $\begin{array}{l}\text { Net Resource/Net } \\
\text { Utilization }\end{array}$ & $\mathbf{2 9 , 6 3 7 . 7}$ & $\mathbf{7 , 3 7 6 . 6}$ & $\mathbf{3 8 , 1 2 0}$ & $\mathbf{9 , 3 4 0 . 0}$ & $\mathbf{4 9 , 2 4 1 . 4}$ & $\mathbf{1 1 , 9 7 2 . 0}$ & $\mathbf{5 3 , 6 7 1 . 4}$ & $\mathbf{1 3 , 5 1 2 . 0}$ \\
\hline
\end{tabular}

Source: Insurance Committee *With inclusion of estimates of Rastriya Beema Samiti **Only till Mid-March 2012

The table shows the contribution of insurance company in Nepal. In this domain if the regulatory would formulated a certain percentage compulsory fund in micro insurance sector, it will indirectly and directly contribute on the rural, women, poor and 
Janapriya Journal of Interdisciplinary Studies, Vol. 2, No.1 (December 2013)

deprived group of Nepal.

Table :3 Mobilization of Insurance premium and status of Investment

\begin{tabular}{|l|l|l|l|l|l|l|l|l|}
\hline $\begin{array}{c}\text { Fiscal } \\
\text { Year }\end{array}$ & \multicolumn{3}{|c|}{$\begin{array}{c}\text { Total Insurance Fees Income } \\
\text { (in million Rs.) }\end{array}$} & $\begin{array}{c}\text { Growth } \\
\text { rate } \\
\text { (percent) }\end{array}$ & \multicolumn{2}{|l|}{ Investment (in million Rs.) } & $\begin{array}{c}\text { Contribution of } \\
\text { insurance fees } \\
\text { income to GDP }\end{array}$ \\
\hline $2005 / 06$ & $3,788.9$ & $2,854.9$ & $6,643.8$ & 16.92 & $15,201.1$ & $3,211.0$ & $18,412.1$ & 1.01 \\
\hline $2006 / 07$ & $4,623.3$ & $3,288.9$ & $7,912.2$ & 19.09 & $18,397.6$ & $3,447.5$ & $21,845.1$ & 1.08 \\
\hline $2007 / 08$ & $5,489.9$ & $3,851.9$ & $9,341.8$ & 18.07 & $20,349.9$ & $4,183.1$ & $24,533.0$ & 1.14 \\
\hline $2008 / 09$ & $6,635.7$ & $4,420.4$ & $11,056.1$ & 18.35 & $26,516.2$ & $5,007.9$ & $31,524.1$ & 1.11 \\
\hline $2009 / 10$ & $8,766.0$ & $6,496.7$ & $15,262.7$ & 38.05 & $29,939.9$ & $5,927.6$ & $35,867.5$ & 1.30 \\
\hline $2010 / 11$ & $10,422.2$ & $7,063.9$ & $17,486.1$ & 14.56 & $42,751.1$ & $7,472.7$ & $50,223.8$ & 1.31 \\
\hline $2011 / 12^{*}$ & $11,600.0$ & $8,100.0$ & $19,700.0$ & 12.66 & $47,600.0$ & 870.0 & $56,300.0$ & 1.41 \\
\hline
\end{tabular}

Source: Economic survey, 2012/13

The table shows regular improvement in the contribution of insurance service fee income to GDP, which can be taken as positive signal in this field. In this context, the business of regulated Nepalese insurers is divided into two core categories: life and general insurance. Life insurance includes products like endowment policies, whole life policies, term policies and pension plans. General insurance covers all other types of insurance including motor policies, fire policies, marine polices, etc. Nepal's insurance penetration (premium as a percentage of gross domestic products) in 201112 is low at 1.50 percent only. It is estimated that less than $6 \%$ of the population has some forms of life insurance, provided either by group of individual policies. The Nepalese economy is primarily rural based. Most of the rural population is illiterate, poor and small holders. More than $25 \%$ of the population lives below the poverty line. The average per capita income of Nepalese people is around U.S. $\$ 700$ only. In this context, micro insurance need to be mainstreamed to support the microfinance program effectively and efficiently.

\section{Suggestion for the Improvement in the Field of Micro -insurance}

- Linking micro finance with micro insurance which facilitate the various related risk.

- Awareness creation program should be introduced in the group and center of microfinance program.

- Insurance Board should take initiatives in widening outreach of micro insurance like IRDA is taking initiatives in widening outreach of micro insurance in India

- Appointment of agent to conduct micro insurance business among the institutional insurance agent, agent appointed can work only with an insurer in case of similar line of business.

- Appointment of motivator to assist the micro insurance business among the person qualified to be an insurance agent, motivator appointed can work only 
with an insurer.

- Commission to be paid to the agent or motivator is mentioned clearly.

- Written agreement with agent must be concluded prior to appointment of such agent and the functions of the agent must be based on agreement.

- Functions and responsibilities of the agents should be mentioned.

- Obligation of insurer to provide basic training to the employees, agent and motivators in respect of micro insurance business administration, management, distribution and claim settlement

- Insurer must manage to pay the claim within 30 days after verification.

- 20 percent of the claim must be paid through insurance agent within 7 days if the claim is found to be genuine.

- Insurer can reimburse the amount paid for settlement of claim from micro insurance pool.

- Leveraging existing network for micro-insurance

- Human Resource is required to be trained to cover the huge untapped market.

- There is a need for developing adequate feedback mechanisms

Micro insurance is a relatively new concept that is still at a nascent stage in developing countries like Nepal. Generally, micro insurance is taken as a means of protecting lowincome households from risks and poverty alleviation. Most of the general insurance companies have not gone in Micro-insurance sector as such. They are limited to the middle and high income people and for the business sector. However, few non-life insurance companies have started to introduce Micro-insurance policies. It is the time to regulate insurance companies to be part of micro insurance developing country like Nepal. They should make mandatory of investment of certain percentage of portfolio in the field of microfinance. The government of Nepal has initiated some positive signal regarding micro insurance by providing subsidies in micro insurance recently.

\section{References}

Anderson, D. R (1974)."The national flood insurance program - problems and potentials", Journal of Risk and Insurance, 41, pp. 579-599,

Asgary, A., Willis, K., Taghevaei, A. A., Rafeian, M. (2004)."Estimating rural households' willingness to pay for health insurance", European Journal of Health Economics, 5, pp. 209-215, 2004.

Bhat, R., Jain, N.(2006)"Factoring affecting the demand for health insurance in a micro insurance scheme", Indian institute of Management Working Paper no. 2006-07-02. 10365

National Bureau of Economic Research, 2006.

K.C. Fatta B(2013). Need for Mainstreaming Micro-Insurance Schemes: Role of Insurance Companies in Nepal, Seminar Paper

Sharma, Puspa Raj (2011). Impact of microfinance on women empowerment. TOLI, Pokhara

Sharma, Puspa Raj (2011). Sustainability fo microfinance institution: An opinion survey. TOLI, Pokhara 
Sharma, Puspa Raj (2004). "Micro-finance: A powerful Tool for Social Transformation, its Challenges and Principles'. The Journal of Nepalese Business Studies, Vol 1.No. 1 pp69-74, P.N. Campus, Pokhara

Sharma, Puspa Raj (2006)."Micro-finance and its Service Development-Challenges and opportunitiy in Nepal". Banijya Sansar Issue 12, Central Department of Management, TU Nepal.

Sharma, Puspa Raj(2003) "Micro-finance Programs and its Strategy to Deliver Services on Poorest of the Poor in Nepal " Seminar Paper presented in a Seminar organized by South Asia Partnership -Nepal, Pokhara, Dec.31

Sharma, Puspa Raj(2004). Millenium Development Goals and International Year of Micro-finance 2005 in the Context of Nepal. The Journal of Nepalese Business Studies, Vol 2.No. 2, P.N. Campus, Pokhara

Sharma, Puspa Raj(2007). Microfinance and Women Empowerment. The Journal of Nepalese Business Studies, Vol 2.No. 2, P.N. Campus, Pokhara

Sharma, Puspa Raj(2012). Micro finance delivery in Nepal - A case study of MEDEP Modality. Janapriya Journal of Interdisciplinary Studies, Vol 1 ,JMC, Pokhara Sharma, Puspa Raj(2012). An Overview of cooperatives in Nepal in the context of international cooperatives year 2012 The Journal of Economics, Vol 5 PNC Ministry of Finance (2012/13) Economic Survey Ministry of Finance (2013/14) Economic Survey

World Bank (2006). Access to Financial Services in Nepal, The World Bank 